\title{
Article \\ Comparative Study for Selective Lithium Recovery via Chemical Transformations during Incineration and Dynamic Pyrolysis of EV Li-Ion Batteries
}

\author{
Srija Balachandran ${ }^{1}$, Kerstin Forsberg ${ }^{1}$, Tom Lemaître ${ }^{2} \mathbb{D}$, Nathália Vieceli ${ }^{2}$, Gabriele Lombardo ${ }^{2} \mathbb{D}$ \\ and Martina Petranikova ${ }^{2, *(\mathbb{D})}$ \\ 1 Department of Chemical Engineering, KTH Royal Institute of Technology, School of Engineering Sciences in \\ Chemistry, Biotechnology and Health, 10044 Stockholm, Sweden; srija@kth.se (S.B.); kerstino@kth.se (K.F.) \\ 2 Department of Chemistry and Chemical Engineering, Industrial Materials Recycling and Nuclear Chemistry, \\ Chalmers University of Technology, 41296 Gothenburg, Sweden; tom.lemaitre14@gmail.com (T.L.); \\ nathalia.vieceli@chalmers.se (N.V.); lombardgabriele@gmail.com (G.L.) \\ * Correspondence: martina.petranikova@chalmers.se
}

check for updates

Citation: Balachandran, S.; Forsberg,

K.; Lemaître, T.; Vieceli, N.;

Lombardo, G.; Petranikova, M.

Comparative Study for Selective

Lithium Recovery via Chemical Transformations during Incineration and Dynamic Pyrolysis of EV Li-Ion Batteries. Metals 2021, 11, 1240.

https://doi.org/10.3390/met11081240

Academic Editor: Felix A. Lopez

Received: 30 June 2021

Accepted: 3 August 2021

Published: 4 August 2021

Publisher's Note: MDPI stays neutral with regard to jurisdictional claims in published maps and institutional affiliations.

Copyright: (c) 2021 by the authors. Licensee MDPI, Basel, Switzerland. This article is an open access article distributed under the terms and conditions of the Creative Commons Attribution (CC BY) license (https:// creativecommons.org/licenses/by/ $4.0 /)$.

\begin{abstract}
Selective leaching of Li from spent LIBs thermally pretreated by pyrolysis and incineration between 400 and $700{ }^{\circ} \mathrm{C}$ for 30,60, and $90 \mathrm{~min}$ followed by water leaching at high temperature and high $\mathrm{L} / \mathrm{S}$ ratio was examined. During the thermal pretreatment $\mathrm{Li}_{2} \mathrm{CO}_{3}$ and $\mathrm{LiF}$ were leached. Along with Li salts, $\mathrm{AlF}_{3}$ was also found to be leached with an efficiency not higher than $3.5 \%$. The time of thermal pretreatment did not have a significant effect on Li leaching efficiency. The leaching efficiency of $\mathrm{Li}$ was higher with a higher $\mathrm{L} / \mathrm{S}$ ratio. At a higher leaching temperature $\left(80^{\circ} \mathrm{C}\right)$, the leaching of $\mathrm{Li}$ was higher due to an increase in the solubility of present Li salts. The highest Li leaching efficiency of nearly $60 \%$ was observed from the sample pyrolyzed at $700{ }^{\circ} \mathrm{C}$ for 60 min under the leaching condition L/S ratio of $20: 1 \mathrm{~mL} \mathrm{~g}^{-1}$ at $80{ }^{\circ} \mathrm{C}$ for $3 \mathrm{~h}$. Furthermore, the use of an excess of $10 \%$ of carbon in a form of graphite during the thermal treatment did not improve the leaching efficiency of Li.
\end{abstract}

Keywords: electric vehicles; Li-ion batteries; a combined method of recycling; pyrolysis; incineration; water leaching

\section{Introduction}

The average life span of Li-ion batteries (LIBs) in electric vehicles (EVs) is expected to be around 8-10 years. This will result in the generation of a huge number of spent LIBs somewhere between 1.1 million tons by 2030 to 5.3 million tons by 2040 in the EU [1]. The disposal of these batteries not only has several environmental impacts due to toxic and flammable electrolytes and other hazards but also results in the loss of valuable metals as waste. Therefore, efficient, and sustainable recycling methods should also grow at the same pace as the EV industries; otherwise, there will be a rapid depletion of metals from the primary supplies. Particularly, recycling cathode materials will have a huge effect from an environmental standpoint, contribute to reducing battery cost and ensure a sustainable supply of materials in the long run $[2,3]$.

Lithium is one of the vital elements for the modern energy revolution and there is an increasing demand for its usage in battery applications. For example, it is projected that the demand for Li in LIBs will expand from 9760 tons in 2015 to 21,520 tons in 2025 [4]. Also, there are problems related to the uneven distribution of $\mathrm{Li}$ in some geographical locations, which could lead to supply risk. For instance, the main global reserves of Li are mostly concentrated in South America and Australia. It has been predicted that there will be a severe scarcity of $\mathrm{Li}$ in the near future [5]. Furthermore, there are high environmental burdens and negative social impacts associated with the extraction of virgin materials [6,7]. 
Recently, Li was added to the list of the European Union's critical materials due to its high economic importance in battery application and supply risk raised due to dependence on other countries $[8,9]$.

The hydrometallurgical processes are efficient in the recycling of LIBs. However, acidbased leaching processes have some drawbacks related to Li recovery, such as a limited number of extractants available to directly recover Li from the leaching solution. Thus, $\mathrm{Li}$ is consequently recovered in the last steps of the hydrometallurgical process. Also, low concentrations of $\mathrm{Li}$ are retained in the raffinate at the end of each solvent extraction stage, which makes Li recovery difficult and uneconomical [10]. Acid-based leaching followed by recovery processes involves complex recycling routes and Li loss occurs at numerous points during the recovery of other metals. A significant amount of Li is lost, as Li forms complex salts with sodium, which is used to treat impurities, extract valuable metals and $\mathrm{pH}$ adjustment. During these processes, there are huge amounts of organic or mineral acids being consumed. Furthermore, another drawback related to the acidbased leaching process involves the consumption of alkali compounds that are needed to neutralize acid leachate liquor as an alkaline condition ( $\mathrm{pH}$ ca. 10-12) is suitable for high recovery and purity of Li products [2]. There are problems raised from the generation of large volumes of acid/alkaline waste, sludge containing heavy metal ions, organic waste, negative carbon dust which further create an extra cost for secondary pollution treatment due to the environmental problems [11].

To address the shortcomings related to Li recycling, combined methods to extract Li selectively before extraction of other valuable metals from spent LIBs are found to be a promising route, including for example thermal treatment followed by water leaching. In this context, the aim of this work is to investigate selective leaching of Li from thermally pretreated waste batteries with water as a leaching agent at high temperature and high $\mathrm{L} / \mathrm{S}$ ratio. The $\mathrm{L} / \mathrm{S}$ ratio indicates the liquid/solid ratio which is the amount of black mass in ' $\mathrm{g}$ ' per volume of leaching liquid in 'mL'. Through the combined methods, Li could be recovered first, and other metals will remain in the black mass which could be recovered in later stages and, thus, Li could be more easily separated from other metals. Furthermore, Li salts show good solubility in water and so water is used as a leaching agent.

The removal of organic compounds such as binder (e.g., PVDF-polyvinylidene fluoride), separator, and graphite is promoted by thermal treatment processes. Particularly, the presence of binder hinders the recovery of metals during the hydrometallurgical processes of leaching and solvent extraction. Two main thermal treatment processes are generally applied, namely incineration and pyrolysis, which are the processes taking place in the presence and absence of oxygen, respectively. The carbon acts as a reducing agent, thereby reducing the metal oxides from higher valence states to their lower valence states, which improves the leaching efficiency of some metals during subsequent leaching processes [12]. This is an in-situ recycling process where the electrode material (graphite) is used to facilitate resource recovery together with the carbon from other organic components. This means no additional reagents are needed during this process, which could further minimize the generation of secondary pollution [11]. Thus, the efficiency of material recovery in the hydrometallurgical process could be enhanced by thermal pretreatment $[11,13]$.

Kuzuhara et al. worked on the incineration process for recovery of Li from sample synthesized with $\mathrm{LCO}\left(\mathrm{LiCoO}_{2}\right)$ powder and activated carbon, where a Li recovery of $90 \%$ was achieved at $500-600{ }^{\circ} \mathrm{C}$ in the form of $\mathrm{Li}_{2} \mathrm{CO}_{3}$. In addition, to achieve a high $\mathrm{Li}$ recovery with high purity, it was suggested to increase the temperature and lower the $\mathrm{F} / \mathrm{Li}$ ratio in the solution [14]. According to Liu et al. [15], a simple and environmentally friendly method of metal recovery from spent LIBs was proposed, which utilized a combined method of treatment: reduction roasting and hydrometallurgical recovery. The roasting of $\mathrm{NMC} 111\left(\mathrm{LiNi}_{1 / 3} \mathrm{Mn}_{1 / 3} \mathrm{Co}_{1 / 3} \mathrm{O}_{2}\right)$ resulted in products such as $\mathrm{Li}_{2} \mathrm{CO}_{3}, \mathrm{Ni}, \mathrm{Co}, \mathrm{MnO}$, and $\mathrm{NiO}$, where $\mathrm{Li}_{2} \mathrm{CO}_{3}$ was first leached with water and the residual solid residue was then subsequently subjected to $\mathrm{H}_{2} \mathrm{SO}_{4}$ leaching. During this process, a Li leaching efficiency of $93.7 \%$ was achieved from the sample roasted at $650{ }^{\circ} \mathrm{C}$ for $30 \mathrm{~min}$. In a work performed 
by Xiao et al. [11], a combined method to recycle $\mathrm{Li}$ as $\mathrm{Li}_{2} \mathrm{CO}_{3}$ was suggested, where the cathode materials were reduced in-situ with graphite as a reductant under vacuum pyrolysis. Later, $\mathrm{Li}_{2} \mathrm{CO}_{3}$ was recovered by water leaching. Li recovery rates of $81.9 \%, 82.7 \%$, and $66.3 \%$ were obtained from LMO, LCO, and NMC respectively at $973 \mathrm{~K}$ for 30 min with a L/S ratio of 4. Peng et al. [4] carried out an environmentally friendly process by combining oxygen-free roasting and wet magnetic separation, where LCO and graphite were roasted in an oxygen-free atmosphere at $1000{ }^{\circ} \mathrm{C}$ for $30 \mathrm{~min}$. The solid residue obtained was then subjected to water leaching where Li was obtained with a high recovery of $98.9 \%$ in the form of $\mathrm{Li}_{2} \mathrm{CO}_{3}$. In a work performed by Jandova et al. [16], a combined process of roastingleaching-crystallization and condensation-precipitation steps to separate $\mathrm{Li}_{2} \mathrm{CO}_{3}$ from $\mathrm{Li} / \mathrm{MnO}_{2}$ batteries were applied. Li extraction of about $80 \%$ was reached with samples roasted at $650{ }^{\circ} \mathrm{C}$ with $\mathrm{Li}_{2} \mathrm{CO}_{3}$ purity of $99.5 \%$ by evaporation of $95 \%$ of water. In another work by Paulino et al. [17], two recycling processes were tested. Firstly, the cathode material was treated with a $\mathrm{KHSO}_{4}$ solution and then calcined at $500{ }^{\circ} \mathrm{C}$ for $5 \mathrm{~h}$. The thermally treated contents were then leached with distilled water for $1 \mathrm{~h}$ at $90{ }^{\circ} \mathrm{C}$. In the next process, incineration of materials was carried out at $500{ }^{\circ} \mathrm{C}$ for $5 \mathrm{~h}$ and then were leached with water. The result showed an improvement in Li recovery after removing carbon, as carbon could be a strong adsorbent for $\mathrm{Li}^{+}$ions. This has resulted in a Li recovery of nearly $90 \%$. From these works, it is evident that hydrometallurgical treatment can be improved by using thermally pretreated battery materials for Li recovery. Even though pyrometallurgical processes have a higher footprint compared to the hydrometallurgical process, a high recovery of Li could be achieved. Thus, thermal pretreatment simplifies hydrometallurgical treatment processes. This work further investigates the comparative study for selective Li recovery from mixed cathode and anode materials of $\mathrm{LiNi}_{1 / 3} \mathrm{Mn}_{1 / 3} \mathrm{Co}_{1 / 3} \mathrm{O}_{2}(\mathrm{NMC111})$ batteries by water leaching exposed to incineration and pyrolysis pretreatments and analyzes the behavior of impurities.

The thermal pretreatment enhances the degradation of cathode materials and results in the formation of water-soluble Li salts. The following section illustrates the mechanism through which $\mathrm{Li}_{2} \mathrm{CO}_{3}$ was formed during the thermal treatments.

Incineration occurs in the presence of oxygen. The high temperature results in the combustion of graphite and organic compounds and the formation of $\mathrm{CO}_{2}$ and $\mathrm{CO}$ according to Equations (1)-(3) [12]. In the presence of $\mathrm{O}_{2}, \mathrm{LiCoO}_{2}$ is reduced by $\mathrm{C}$ and $\mathrm{CO}$ to $\mathrm{Co}_{3} \mathrm{O}_{4}, \mathrm{Li}_{2} \mathrm{CO}_{3}$, and $\mathrm{CO}_{2}$ according to Equations (4) and (5), $\mathrm{LiMn}_{2} \mathrm{O}_{4}$ is reduced by $\mathrm{C}$ and $\mathrm{CO}$ to $\mathrm{Mn}_{3} \mathrm{O}_{4}, \mathrm{MnO}_{2}, \mathrm{Li}_{2} \mathrm{O}$, and $\mathrm{CO}_{2}$ according to Equations (6)-(9). Furthermore, $\mathrm{Li}_{2} \mathrm{O}$ reacts with $\mathrm{CO}_{2(\mathrm{~g})}$ to form $\mathrm{Li}_{2} \mathrm{CO}_{3}$ according to Equations (10) and (11). Similarly, in the presence of $\mathrm{O}_{2}, \mathrm{LiNiO}_{2}$ is reduced by $\mathrm{C}$ and $\mathrm{CO}$ to $\mathrm{Ni}_{3} \mathrm{O}_{4}, \mathrm{Li}_{2} \mathrm{CO}_{3}$, and $\mathrm{CO}_{2}$ according to Equation (12).

$$
\begin{gathered}
\mathrm{C}_{(\mathrm{s})}+\mathrm{O}_{2(\mathrm{~g})} \rightarrow \mathrm{CO}_{2(\mathrm{~g})} \\
2 \mathrm{C}_{(\mathrm{s})}+\mathrm{O}_{2(\mathrm{~g})} \rightarrow 2 \mathrm{CO}_{(\mathrm{g})} \\
2 \mathrm{CO}_{(\mathrm{g})}+\mathrm{O}_{2(\mathrm{~g})} \rightarrow 2 \mathrm{CO}_{2(\mathrm{~g})} \\
3 \mathrm{LiCoO}_{2(\mathrm{~s})}+2.5 \mathrm{C}_{(\mathrm{s})}+2.25 \mathrm{O}_{2(\mathrm{~g})} \rightarrow \mathrm{Co}_{3} \mathrm{O}_{4}+1.5 \mathrm{Li}_{2} \mathrm{CO}_{3(\mathrm{~s})}+\mathrm{CO}_{2(\mathrm{~g})} \\
3 \mathrm{LiCoO}_{2(\mathrm{~s})}+2.5 \mathrm{CO}_{(\mathrm{g})}+\mathrm{O}_{2(\mathrm{~g})} \rightarrow \mathrm{Co}_{3} \mathrm{O}_{4}+1.5 \mathrm{Li}_{2} \mathrm{CO}_{3(\mathrm{~s})}+\mathrm{CO}_{2(\mathrm{~g})} \\
12 \mathrm{LiMn}_{2} \mathrm{O}_{4(\mathrm{~s})}+6 \mathrm{C}_{(\mathrm{s})}+\mathrm{O}_{2(\mathrm{~g})} \rightarrow 8 \mathrm{Mn}_{3} \mathrm{O}_{4(\mathrm{~s})}+6 \mathrm{Li}_{2} \mathrm{O}_{(\mathrm{s})}+6 \mathrm{CO}_{2(\mathrm{~g})} \\
6 \mathrm{LiMn}_{2} \mathrm{O}_{4(\mathrm{~s})}+5 \mathrm{CO}_{(\mathrm{g})} \rightarrow 4 \mathrm{Mn}_{3} \mathrm{O}_{4(\mathrm{~s})}+3 \mathrm{Li}_{2} \mathrm{O}_{(\mathrm{s})}+5 \mathrm{CO}_{2(\mathrm{~g})} \\
2 \mathrm{LiMn}_{2} \mathrm{O}_{4(\mathrm{~s})}+\mathrm{C}_{(\mathrm{s})}+1.5 \mathrm{O}_{2(\mathrm{~g})} \rightarrow 4 \mathrm{MnO}_{2(\mathrm{~s})}+\mathrm{Li}_{2} \mathrm{O}_{(\mathrm{s})}+\mathrm{CO}_{2(\mathrm{~g})} \\
2 \mathrm{LiMn}_{2} \mathrm{O}_{4(\mathrm{~s})}+\mathrm{CO}_{(\mathrm{g})}+\mathrm{O}_{2(\mathrm{~g})} \rightarrow 4 \mathrm{MnO}_{2(\mathrm{~s})}+\mathrm{Li}_{2} \mathrm{O}_{(\mathrm{s})}+\mathrm{CO}_{2(\mathrm{~g})} \\
\mathrm{Li}_{2} \mathrm{O}_{(\mathrm{s})}+\mathrm{CO}_{2(\mathrm{~g})} \rightarrow \mathrm{Li}_{2} \mathrm{CO}_{3(\mathrm{~s})} \\
2 \mathrm{Li}_{2} \mathrm{O}_{(\mathrm{s})}+2 \mathrm{CO}_{(\mathrm{g})}+\mathrm{O}_{2(\mathrm{~g})} \rightarrow 2 \mathrm{Li}_{2} \mathrm{CO}_{3(\mathrm{~s})} \\
3 \mathrm{LiNiO}_{2}+2.5 \mathrm{C}_{(\mathrm{s})}+2.25 \mathrm{O}_{2(\mathrm{~g})} \rightarrow \mathrm{Ni}_{3} \mathrm{O}_{4}+1.5 \mathrm{Li}_{2} \mathrm{CO}_{3(\mathrm{~s})}+\mathrm{CO}_{2(\mathrm{~g})}
\end{gathered}
$$


The pyrolysis process takes place in a nitrogen atmosphere. The carbothermic reduction of metal oxides is favored by the carbon present in the sample through a $\mathrm{CO}$ intermediate, along with the formation of $\mathrm{CO}_{2}$ and $\mathrm{CO}$ [16]. $\mathrm{LiCoO}_{2}$ is converted to $\mathrm{Co}, \mathrm{CoO}, \mathrm{Li}_{2} \mathrm{O}$, $\mathrm{CO}$, and $\mathrm{CO}_{2}$ at high temperatures according to Equations (13)-(17). Thus, $\mathrm{Li}_{2} \mathrm{O}$ formed results in the formation of $\mathrm{Li}_{2} \mathrm{CO}_{3}$ reacting with $\mathrm{CO}_{2}$ (Equation (10)). Also, $\mathrm{LiCoO}_{2}$ is converted to $\mathrm{Co}, \mathrm{Li}_{2} \mathrm{CO}_{3}$, and gases $\left(\mathrm{CO}\right.$ and $\left.\mathrm{CO}_{2}\right)$ according to Equations (18) and (19). Thus, the main products of carbothermic reduction are $\mathrm{Co}$ and $\mathrm{Li}_{2} \mathrm{CO}_{3}$. $\mathrm{LiMn}_{2} \mathrm{O}_{4}$ is converted to $\mathrm{Mn}_{3} \mathrm{O}_{4}, \mathrm{Li}_{2} \mathrm{CO}_{3}, \mathrm{Li}_{2} \mathrm{O}, \mathrm{MnO}, \mathrm{CO}$, and $\mathrm{CO}_{2}$, according to Equations (20)-(22). $\mathrm{LiNiO}_{2}$ is converted to $\mathrm{Ni}, \mathrm{Li}_{2} \mathrm{CO}_{3}, \mathrm{Li}_{2} \mathrm{O}, \mathrm{NiO}, \mathrm{CO}$, and $\mathrm{CO}_{2}$ according to Equations (23)-(27).

$$
\begin{gathered}
4 \mathrm{LiCoO}_{2(\mathrm{~s})}+3 \mathrm{C}_{(\mathrm{s})} \rightarrow 2 \mathrm{Li}_{2} \mathrm{O}_{(\mathrm{s})}+4 \mathrm{Co}_{(\mathrm{s})}+3 \mathrm{CO}_{2(\mathrm{~g})} \\
4 \mathrm{LiCoO}_{2(\mathrm{~s})}+\mathrm{C}_{(\mathrm{s})} \rightarrow 2 \mathrm{Li}_{2} \mathrm{O}_{(\mathrm{s})}+4 \mathrm{CoO}_{(\mathrm{s})}+\mathrm{CO}_{2(\mathrm{~g})} \\
2 \mathrm{LiCoO}_{2(\mathrm{~s})}+3 \mathrm{C}_{(\mathrm{s})} \rightarrow \mathrm{Li}_{2} \mathrm{O}_{(\mathrm{s})}+2 \mathrm{Co}_{(\mathrm{s})}+3 \mathrm{CO}_{(\mathrm{g})} \\
2 \mathrm{LiCoO}_{2(\mathrm{~s})}+\mathrm{C}_{(\mathrm{s})} \rightarrow \mathrm{Li}_{2} \mathrm{O}_{(\mathrm{s})}+2 \mathrm{CoO}_{(\mathrm{s})}+\mathrm{CO}_{(\mathrm{g})} \\
2 \mathrm{LiCoO}_{2(\mathrm{~s})}+3 \mathrm{CO}_{(\mathrm{g})} \rightarrow \mathrm{Li}_{2} \mathrm{O}_{(\mathrm{s})}+2 \mathrm{Co}_{(\mathrm{s})}+3 \mathrm{CO}_{2(\mathrm{~g})} \\
2 \mathrm{LiCoO}_{2(\mathrm{~s})}+3 \mathrm{CO}_{(\mathrm{g})} \rightarrow 2 \mathrm{Co}_{(\mathrm{s})}+\mathrm{Li}_{2} \mathrm{CO}_{3(\mathrm{~s})}+2 \mathrm{CO}_{2(\mathrm{~g})} \\
6 \mathrm{LiCoO}_{2(\mathrm{~s})}+5 \mathrm{C}_{(\mathrm{s})} \rightarrow 6 \mathrm{Co}_{(\mathrm{s})}+3 \mathrm{Li}_{2} \mathrm{CO}_{3(\mathrm{~s})}+\mathrm{CO}_{2(\mathrm{~g})}+\mathrm{CO}_{(\mathrm{g})} \\
2.4 \mathrm{LiMn}_{2} \mathrm{O}_{4(\mathrm{~s})}+\mathrm{C}_{(\mathrm{s})} \rightarrow 1.2 \mathrm{Li}_{2} \mathrm{O}_{(\mathrm{s})}+1.6 \mathrm{Mn}_{3} \mathrm{O}_{4(\mathrm{~s})}+\mathrm{CO}_{2(\mathrm{~g})} \\
3 \mathrm{LiMn}_{2} \mathrm{O}_{4(\mathrm{~s})}+2.5 \mathrm{CO}_{(\mathrm{g})} \rightarrow 2 \mathrm{Mn}_{3} \mathrm{O}_{4(\mathrm{~s})}+1.5 \mathrm{Li}_{2} \mathrm{CO}_{3(\mathrm{~s})}+\mathrm{CO}_{2(\mathrm{~g})} \\
2 \mathrm{LiMn}_{2} \mathrm{O}_{4(\mathrm{~s})}+2 \mathrm{C}_{(\mathrm{s})} \rightarrow \mathrm{Li}_{2} \mathrm{CO}_{3(\mathrm{~s})}+4 \mathrm{MnO}_{(\mathrm{s})}+\mathrm{CO}_{(\mathrm{g})} \\
4 \mathrm{LiNiO}_{2(\mathrm{~s})}+\mathrm{C}_{(\mathrm{s})} \rightarrow 2 \mathrm{Li}_{2} \mathrm{O}_{(\mathrm{s})}+4 \mathrm{NiO}_{(\mathrm{s})}+\mathrm{CO}_{2(\mathrm{~g})} \\
2 \mathrm{LiNiO}_{2(\mathrm{~s})}+3 \mathrm{C}_{(\mathrm{s})} \rightarrow \mathrm{Li}_{2} \mathrm{O}_{(\mathrm{s})}+2 \mathrm{Ni}_{(\mathrm{s})}+3 \mathrm{CO}_{(\mathrm{g})} \\
2 \mathrm{LiNiO}_{2(\mathrm{~s})}+\mathrm{C}_{(\mathrm{s})} \rightarrow \mathrm{Li}_{2} \mathrm{O}_{(\mathrm{s})}+2 \mathrm{NiO}_{(\mathrm{s})}+\mathrm{CO}_{(\mathrm{g})} \\
2 \mathrm{LiNiO}_{2}(\mathrm{~s})+3 \mathrm{CO}_{(\mathrm{g})} \rightarrow 2 \mathrm{Ni}_{(\mathrm{s})}+\mathrm{Li}_{2} \mathrm{CO}_{3(\mathrm{~s})}+2 \mathrm{CO}_{2(\mathrm{~g})} \\
6 \mathrm{LiNiO}_{2(\mathrm{~s})}+5 \mathrm{C}_{(\mathrm{s})} \rightarrow 6 \mathrm{Ni}_{(\mathrm{s})}+3 \mathrm{Li}_{2} \mathrm{CO}_{3(\mathrm{~s})}+\mathrm{CO}_{2(\mathrm{~g})}+\mathrm{CO}_{(\mathrm{g})}
\end{gathered}
$$

\section{Materials and Methods}

\subsection{Thermal Treatment}

The NMC111 type batteries used for this work were provided by Volvo Cars (Sweden). The batteries were first dismantled to remove the plastic cover and then both electrodes (cathode and anode) and the separator were cut into small pieces manually. The samples were then subjected to two different thermal treatment processes in the temperature range between 400 and $700{ }^{\circ} \mathrm{C}$ under different treatment times (30,60, and $\left.90 \mathrm{~min}\right)$, as described by Lombardo et al. [12]. For all of the experiments, equal quantities of mixed electrodes along with the separator were used, except for the test performed with excess graphite, where $10 \%$ more graphite was added.

\subsection{Chemicals Used}

For the experiments, Nitric acid $\left(\mathrm{HNO}_{3}, \geq 69 \%\right.$, ACS reagent, Sigma-Aldrich, St. Louis, MO, USA), hydrochloric acid ( $\mathrm{HCl}, 37 \%$, ACS reagent, Sigma-Aldrich, St. Louis, MO, USA), Milli-Q water, and a syringe filter $(0.45 \mu \mathrm{m}$, Fischer Scientific, Hampton, NH, USA) were used. 


\subsection{Analytical Techniques}

The total concentration of metals in the samples after thermal treatment was determined by ICP-OES (Inductively Coupled Plasma-Optical Emission Spectrometry) using an iCAP ${ }^{\mathrm{TM}} 6000$ Series ICP-OES (Thermo Fisher Scientific, Waltham, MA, USA). Aqua regia ( $\mathrm{HCl}: \mathrm{HNO}_{3}=3: 1$ ) was used to digest the thermally pretreated samples using a hot plate at approximately $80^{\circ} \mathrm{C}$ and magnetic stirring for $5 \mathrm{~h}$. After digestion, the samples were filtered using a syringe filter and diluted using $0.5 \mathrm{M} \mathrm{HNO}_{3}$ solution to determine their elemental composition by ICP-OES analysis.

X-ray powder diffraction (XRPD) was used to characterized the solid samples and it was conducted using a Siemens D5000 X-ray diffractometer, Midland, ON, Canada with an accelerator voltage of $40 \mathrm{kV}$ and a current of $40 \mathrm{~mA}$. Cu K-radiation was used, and the scans included a $2 \Theta$ range from $10^{\circ}$ to $100^{\circ}$. Also, a sample rotation speed of $15 \mathrm{rpm}$ was set. The diffraction data obtained were identified by comparing with standard data for known compounds using JCPDS database.

\subsection{Leaching Experiment and Analytical Procedure}

Leaching experiments were carried out using Milli-Q water as a leaching agent. Both ground untreated and thermally treated samples were used for the experiments. Different $\mathrm{L} / \mathrm{S}$ ratios (10:1 and 20:1 $\mathrm{mL} \mathrm{g}^{-1}$ ) were used, and the experiments were performed both at room temperature (RT) of around 23 and at $80^{\circ} \mathrm{C}$ with a magnetic stirring speed of $300 \mathrm{rpm}$ for $3 \mathrm{~h}$. At the end of each experiment, the leachate was collected and filtered through a syringe filter. Before analyzing the metal content of each sample using ICP-OES, each sample was diluted with $0.5 \mathrm{M} \mathrm{HNO}_{3}$. By comparing the concentration of each metal in the leachate to the initial metal content in the solid samples obtained by aqua regia digestion, the leaching efficiency was calculated using Equation (28). All of the experiments were performed in triplicate under identical conditions. Using a thermocouple, the solution temperature was measured and the temperature within $\pm 1 \%$ set value was maintained by adjusting the heater output.

$$
\eta_{\mathrm{i}}=\frac{\mathrm{C}_{\mathrm{i}} \mathrm{V}}{\mathrm{m}_{0} \omega \mathrm{i}} \times 100
$$

where, $\mathrm{C}_{\mathrm{i}}\left(\mathrm{mgL}^{-1}\right)$ is the concentration of metal ion $\mathrm{i}$ in the solution, $\mathrm{V}(\mathrm{L})$ is the volume of leaching solution, $\mathrm{m}_{0}(\mathrm{mg})$ is the mass of pretreated material, and $\omega_{\mathrm{i}}$ is the weight content of element $i$ in the sample.

\subsection{Evaporative Crystallization}

To recover the lithium salts from the leachate, the solution was first filtered using a filter paper to separate the leach residue. The water present in the filtrate was evaporated by heating the solution to $100{ }^{\circ} \mathrm{C}$ and the precipitate was collected. Both the leach residue and precipitates were dried $\left(24 \mathrm{~h}\right.$ at $\left.80^{\circ} \mathrm{C}\right)$, and different solid phases present in these samples were characterized by XRPD analysis.

\section{Results}

\subsection{Elemental Composition of Solid Samples}

The initial weight content of metals determined by the digestion of solid samples in aqua regia obtained at different treatment conditions is tabulated in Table 1. These data were used for the calculation of leaching efficiency. 
Table 1. Composition of thermally treated samples and untreated sample.

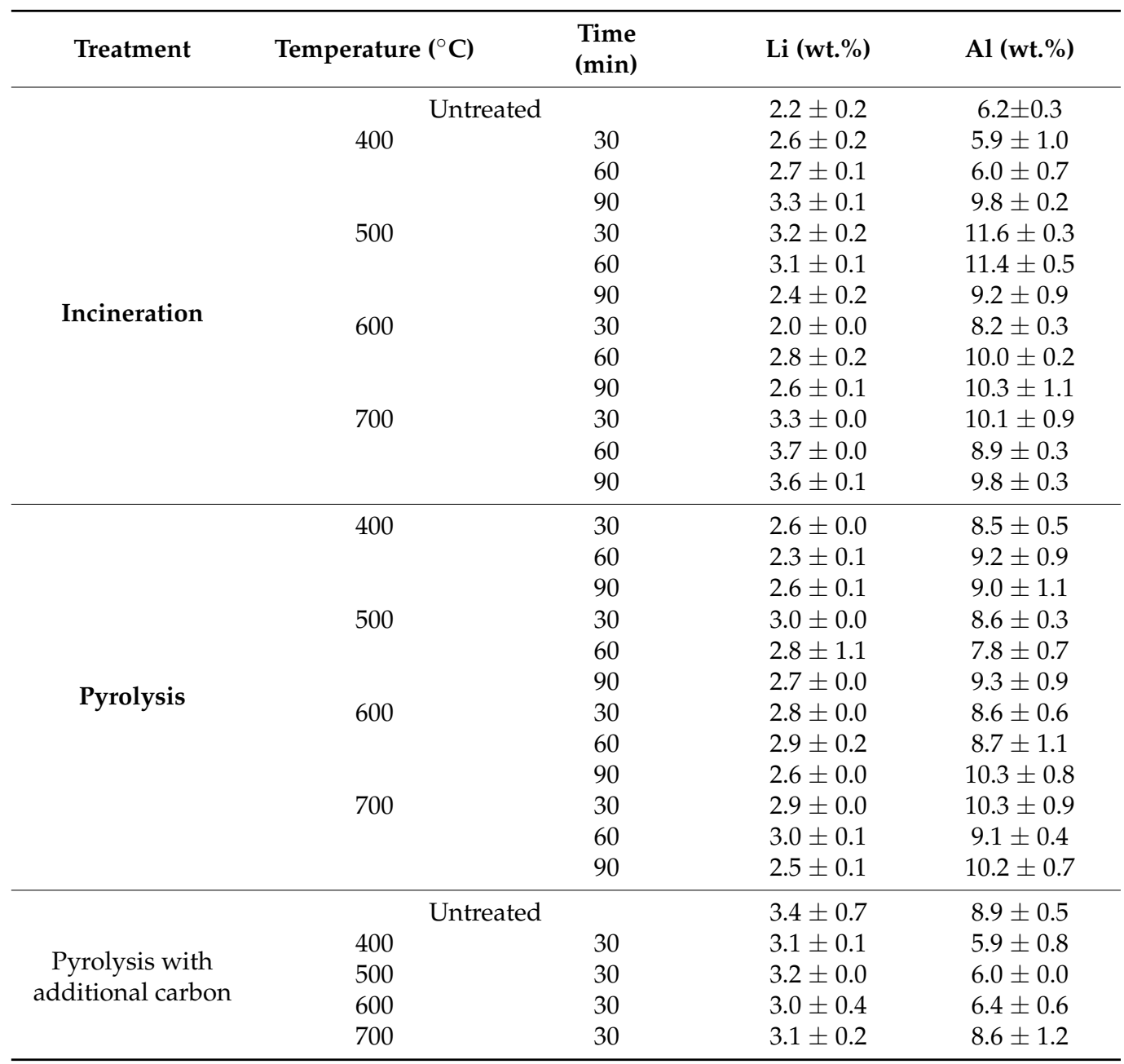

\subsection{The Effect of Thermal Treatment on Li Leaching Efficiency}

The leaching efficiency of the untreated sample under the leaching condition of $\mathrm{L} / \mathrm{S}$ ratio of $20: 1 \mathrm{~mL} \mathrm{~g}^{-1}, 80^{\circ} \mathrm{C}$, and $3 \mathrm{~h}$ was found to be only $7.5 \%$. It was possible to recover $\mathrm{Li}$ from the lithium salts present in the electrolyte by leaching the untreated sample with water. Figure 1a shows the effect of temperature on the leaching of Li from the products pyrolyzed between 400 and $700{ }^{\circ} \mathrm{C}$. The pyrolysis treatment had a positive effect on the $\mathrm{Li}$ leaching efficiency, and it can be seen that the leaching of $\mathrm{Li}$ rises with the increase in treatment temperature. At $400{ }^{\circ} \mathrm{C}$, the leaching efficiency was found to be around $10 \%$. The low leaching efficiency could be related to the partial decomposition of metal oxides at the given temperature. The carbothermic reduction of metal oxides was accelerated along with increasing treatment temperatures by $\mathrm{C}$ and $\mathrm{CO}$ present in the system and resulted in the formation of an increased amount of leachable Li salts, which resulted in an improved leaching efficiency. At $700{ }^{\circ} \mathrm{C}, 60 \%$ of $\mathrm{Li}$ was leached, which was the highest among all conditions. The change in thermal treatment time did not have a significant effect on the leaching efficiency of $\mathrm{Li}$, with less than $4 \%$ difference, at all the temperatures. This could be because of the unreacted lithium metals oxides that are still present in the samples after 60 min of pyrolysis, which could be seen in the X-ray diffraction analysis (XRD) studies as shown in Figure 2 due to lack of carbothermic reduction agent.

Overall, the leaching efficiency of Li obtained from samples after incineration was much lower than from the pyrolysis which can be seen by comparing Figure $1 \mathrm{a}, \mathrm{b}$. This could be because of variation in the kinetics in the oxidation of carbon to $\mathrm{CO}_{2}$ and the carbothermic reduction of metal oxides. In addition, the leaching efficiency at 400 and 
$500{ }^{\circ} \mathrm{C}$ was similar (nearly $15 \%$ ) at all the treatment times. However, for 600 and $700{ }^{\circ} \mathrm{C}$, the leaching efficiency was comparatively higher after $30 \mathrm{~min}$ and after that, it decreased and reached similar efficiencies as of the other two conditions. At higher temperatures, most of the carbon oxidized to $\mathrm{CO}_{2}$ before the carbothermic reduction of metal oxides.
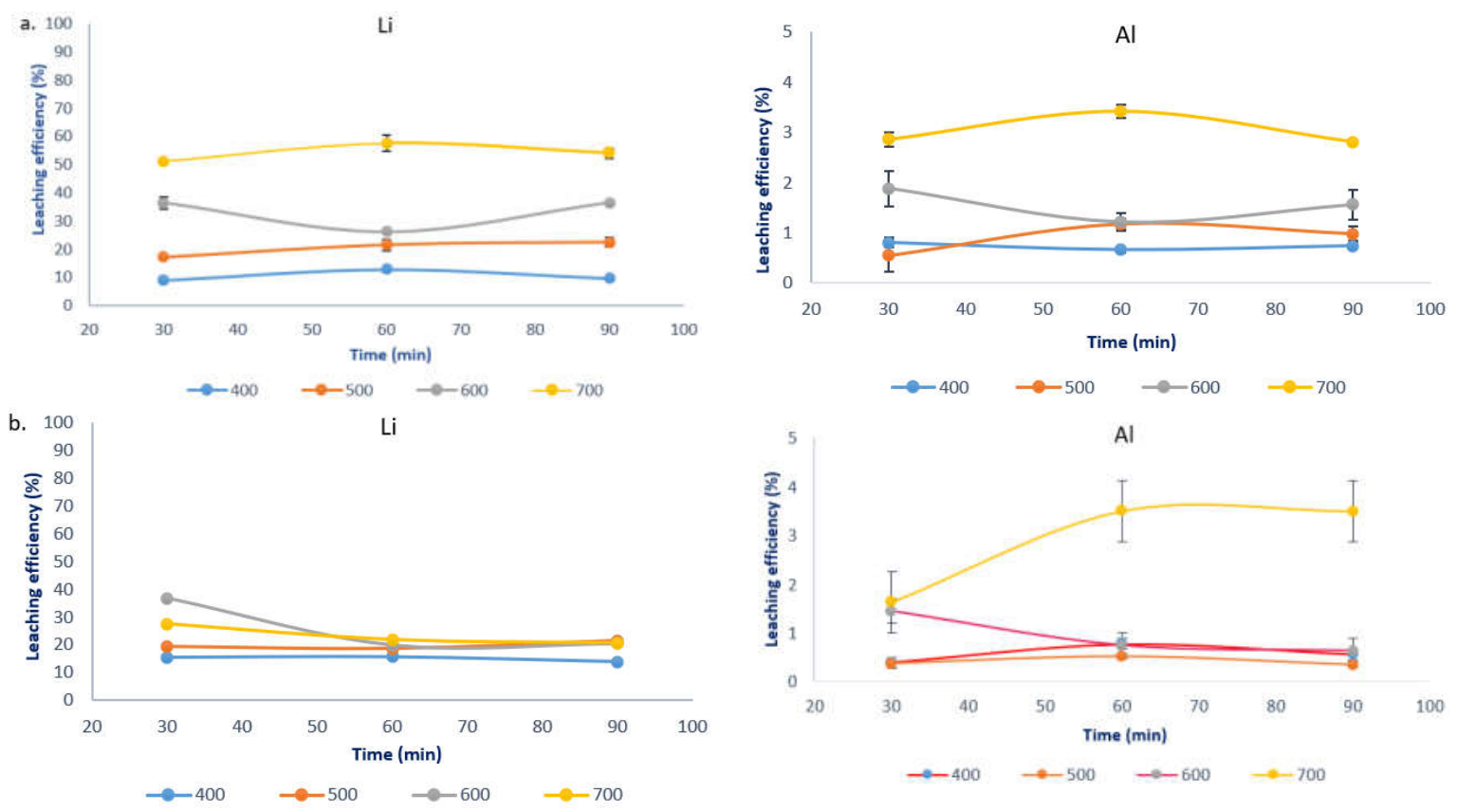

Figure 1. The effect of thermal treatment temperature and time on $\mathrm{Li}$ and $\mathrm{Al}$ leaching efficiency: (a) pyrolysis and (b) incineration (Leaching condition: $\mathrm{L} / \mathrm{S}$ ratio $=20: 1 \mathrm{mLg}^{-1}, 80^{\circ} \mathrm{C}, 300 \mathrm{rpm}$, and $3 \mathrm{~h}$ ).

\subsection{The Effect of $L / S$ Ratio on the Leaching Efficiency of $L i$}

The effect of $\mathrm{L} / \mathrm{S}$ ratio on the water leaching of Li performed at $80^{\circ} \mathrm{C}$, stirring of $300 \mathrm{rpm}$ for $3 \mathrm{~h}$ at two different $\mathrm{L} / \mathrm{S}$ ratios of 10:1 and 20:1 $\mathrm{mL} \mathrm{g}^{-1}$, from samples pyrolyzed and incinerated between 400 and $700{ }^{\circ} \mathrm{C}$ for 30, 60, and $90 \mathrm{~min}$ are shown in the Figure $3 \mathrm{a}, \mathrm{b}$. A similar trend after both pyrolysis and incineration at two different leaching conditions was observed. The leaching efficiency of Li was higher at higher L/S ratio. A larger amount of Li can be dissolved at higher L/S ratio when the dissolution is limited by the solubility. Additionally, the decrease in the pulp density can promote a more efficient mixing effect and facilitate reactions dependent on mass transfer between the solids and the liquid phase.

\subsection{The Effect of Leaching Temperature on the Leaching Efficiency of Li}

The effect of leaching temperature on the water leaching of Li performed at the stirring of $300 \mathrm{rpm}$ for $3 \mathrm{~h}$ with an L/S ratio $20: 1 \mathrm{~mL} \mathrm{~g}^{-1}$ at two different leaching temperatures: $80^{\circ} \mathrm{C}$ and RT from samples pyrolyzed and calcined between 400 and $700{ }^{\circ} \mathrm{C}$ for 30,60 , and $90 \mathrm{~min}$ are shown in Figure $4 \mathrm{a}, \mathrm{b}$. At a higher leaching temperature, the leaching of $\mathrm{Li}$ is higher for all the thermal treatment temperatures. This is due to the increase in solubility of $\mathrm{Li}$ salts with the increase in the temperature. Initially, the samples contain $\mathrm{Li}_{2} \mathrm{CO}_{3}$ which solubility decreases with the increase in the temperature, however, the presence of other $\mathrm{Li}$ products and anions $(\mathrm{F})$ that could be more easily leached at higher temperatures could affect the final leaching efficiencies. The formation of $\mathrm{LiF}$ by the reaction of $\mathrm{Li}_{2} \mathrm{O}$ and $\mathrm{Li}_{2} \mathrm{CO}_{3}$ with $\mathrm{HF}$ generated by the degradation of PVDF binder can happen during the thermal treatment according to Equations (29) and (30) [18,19]. The presence of $\mathrm{LiF}$ was also confirmed by XRD analysis of the samples by using the powder (from pyrolysis $30 \mathrm{~min}$ at $700{ }^{\circ} \mathrm{C}$ ) obtained after the evaporative crystallization of the leaching solution free of 
leaching residue as shown in Figure 5. Therefore, due to the presence of a mixture of $\mathrm{Li}$ salts, the decrease in solubility of $\mathrm{Li}_{2} \mathrm{CO}_{3}$ with an increase in temperature might deviate.

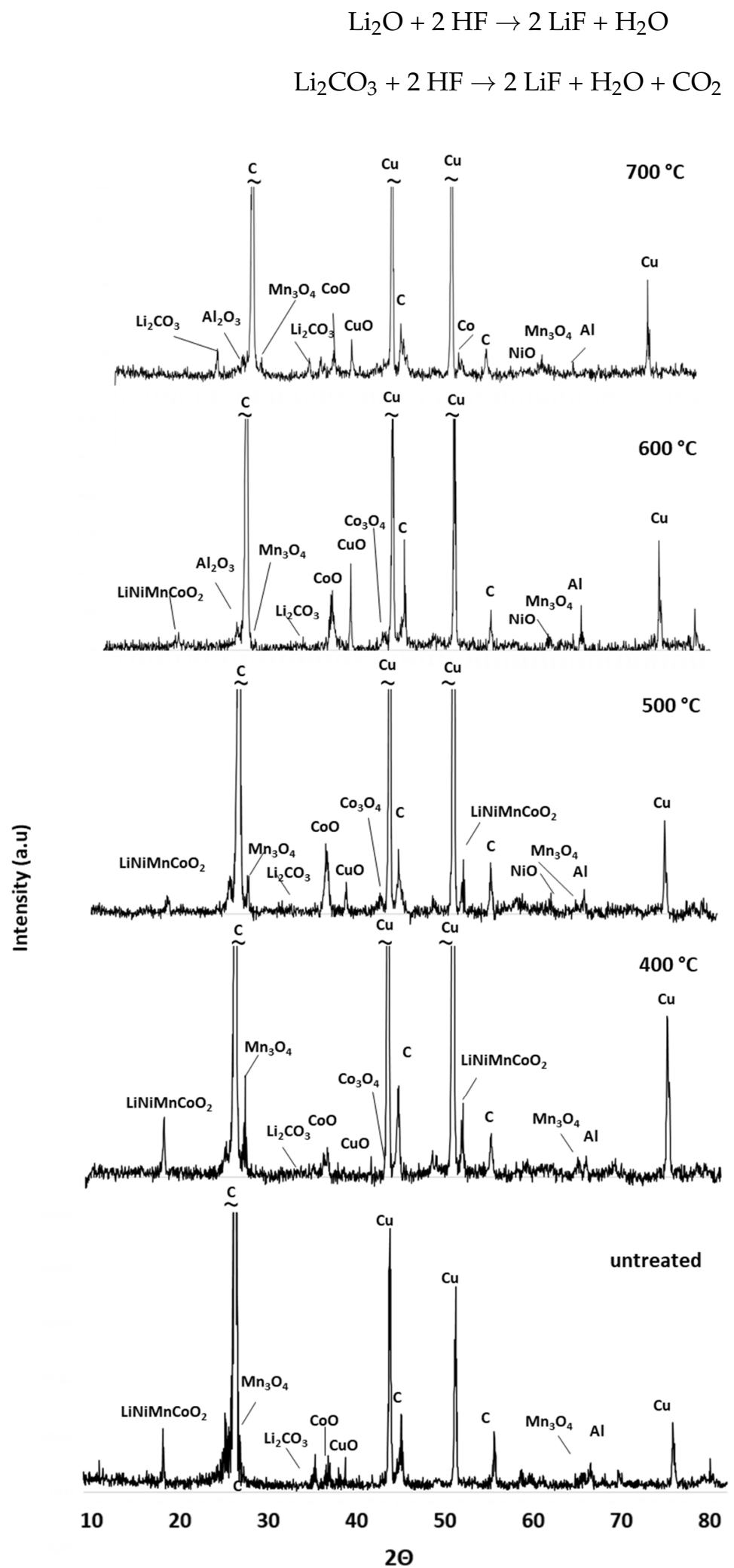

Figure 2. XRD diffractograms of samples after $60 \mathrm{~min}$ of pyrolysis at $400,500,600$, and $700{ }^{\circ} \mathrm{C}$. 

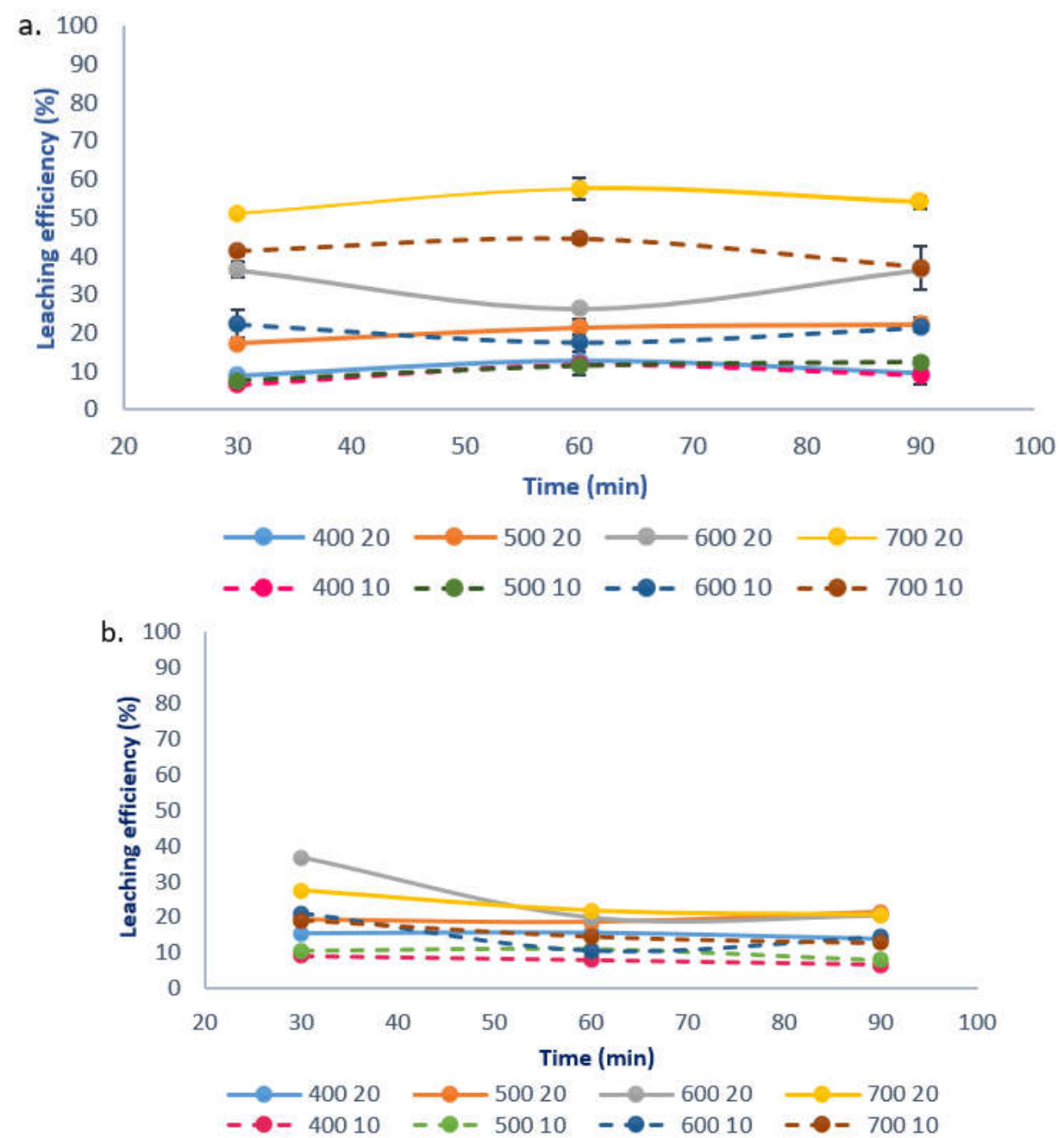

Figure 3. The effect of L/S ratio on Li leaching efficiency: (a) pyrolysis and (b) incineration (Leaching condition: $\mathrm{L} / \mathrm{S}$ ratio $=20: 1$ and 10:1 $\mathrm{mL} \mathrm{g}^{-1}, 80^{\circ} \mathrm{C}, 300 \mathrm{rpm}$, and $3 \mathrm{~h}$ ).

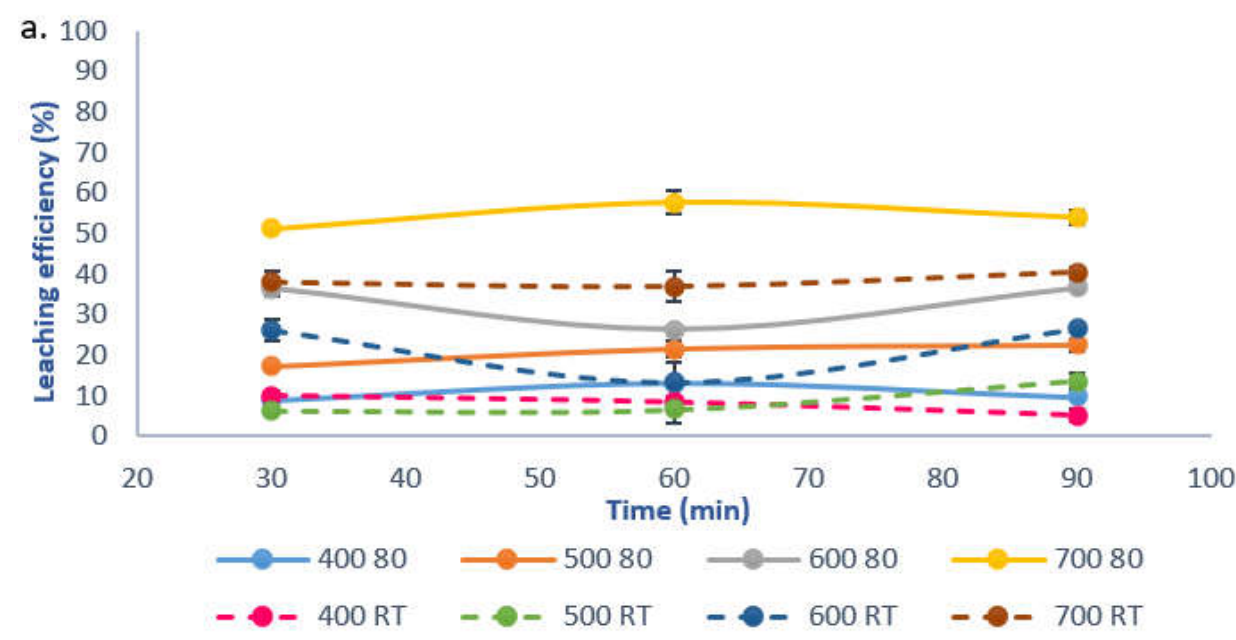

Figure 4. Cont. 


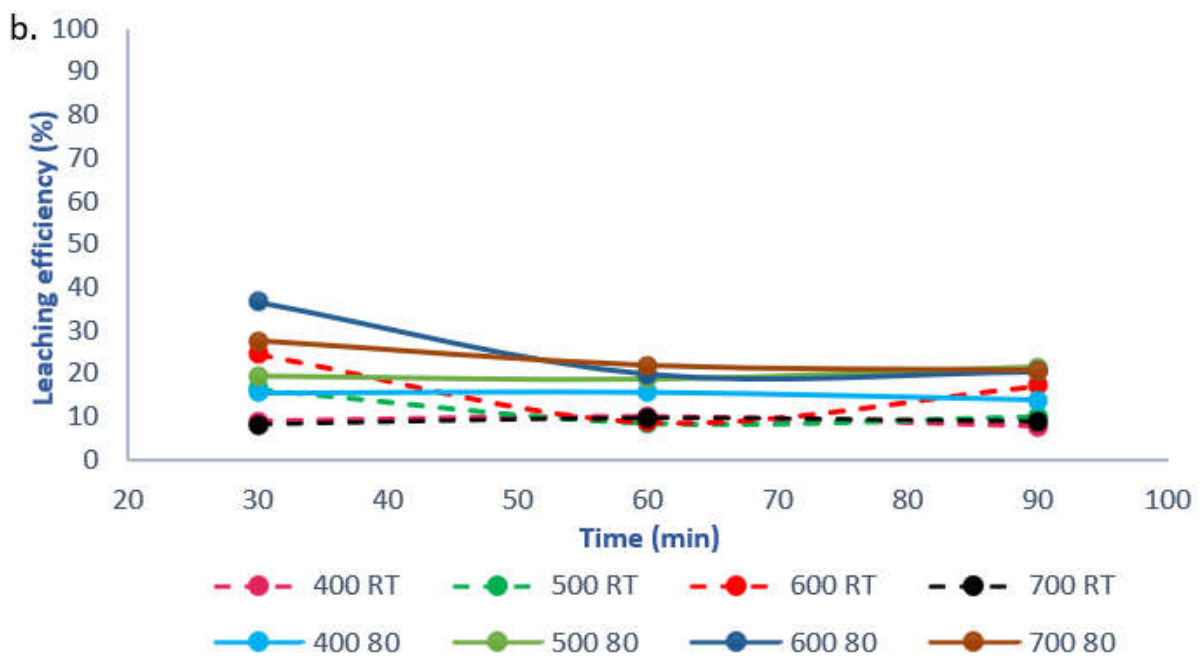

Figure 4. The effect of leaching temperature on Li leaching efficiency: (a) pyrolysis and (b) incineration (Leaching condition: (a). $\mathrm{L} / \mathrm{S}$ ratio $=20: 1 \mathrm{~mL} \mathrm{~g}^{-1}, 80^{\circ} \mathrm{C}$ and $\mathrm{RT}, 300 \mathrm{rpm}$, and $3 \mathrm{~h}$ ). $\mathrm{RT}$ : room temperature.

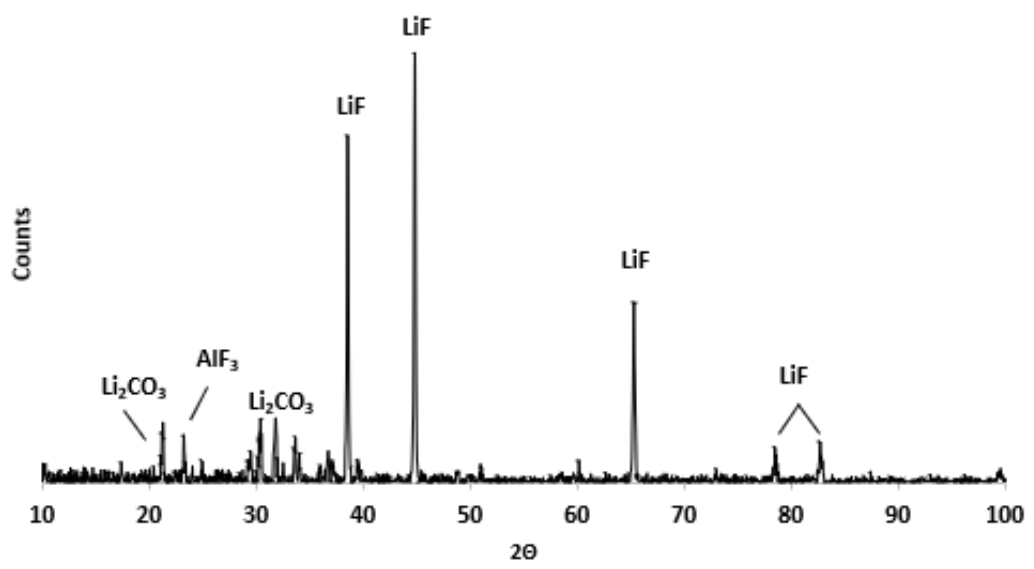

Figure 5. XRD diffractogram of crystallization product of the solution after leaching pyrolyzed sample $\left(700^{\circ} \mathrm{C}\right.$ and $\left.30 \mathrm{~min}\right)$.

The results from XRD studies carried out using leaching residues from pyrolysis treatment at different temperatures and leached with water using an $\mathrm{L} / \mathrm{S}$ ratio of $20: 1 \mathrm{~mL} \mathrm{~g}^{-1}$, $80{ }^{\circ} \mathrm{C}$, and $300 \mathrm{rpm}$ for $3 \mathrm{~h}$ are shown in Figure 6 . Also, the result from thermally untreated samples is shown. The untreated sample predominantly shows the presence of NMC cathode materials and graphite (represented in the diffractograms as C) and there is no formation of leachable Li salts. After the thermal pretreatment, the intensity of the peaks of NMC oxides decreased when compared to the untreated sample which could be explained by the reduction of the mixed oxides during the thermal treatment. Yet, there are some unreacted NMC materials still present after the thermal pretreatment which indicates that not all NMC materials were reduced. In addition, at 600 and $700{ }^{\circ} \mathrm{C}$, peaks of $\mathrm{Li}_{2} \mathrm{CO}_{3}$ and $\mathrm{LiF}$ were seen in the leaching residue which indicated that Li salts were not completely leached. Therefore, the reasons for the low efficiency (only nearly 60\%, which was the maximum efficiency achieved among all the experimental results) of Li could be either due to the presence of unreacted NMC cathode materials in the sample or not all Li salts formed were completely leached with water (e.g., oxide, $\mathrm{Li}_{2} \mathrm{O}$ ).

\subsection{Effect of Addition of Excess Carbon}

The XRD analysis results at different thermal treatment conditions shown in Figure 6 show the presence of peaks of NMC cathode materials which means that some Li is 
being trapped in the unconverted cathode possibly due to the lack of available carbon for reduction. So, an excess of carbon was added to test if an excessive amount of carbon would be beneficial to promote a more complete carbothermic reduction of NMC material. The effect of using excess carbon on leaching of Li performed at the stirring of $300 \mathrm{rpm}$ for $1 \mathrm{~h}$ with an $\mathrm{L} / \mathrm{S}$ ratio $20: 1 \mathrm{~mL} \mathrm{~g}^{-1}$ at $80^{\circ} \mathrm{C}$ from samples pyrolyzed at $400,500,600$, and $700{ }^{\circ} \mathrm{C}$ for $30 \mathrm{~min}$ is shown in Figure 7. It can be observed that not much improvement in leaching of Li was observed by having additional carbon during the thermal pretreatment and the maximum efficiency was found to be nearly $30 \%$. This could be because graphite being a stable form of carbon and does not help in enhancing leaching efficiency. A decrease in the leaching efficiency was observed which might be due to the presence of carbon which could act as an adsorbent for $\mathrm{Li}^{+}$ions and further decrease the leaching efficiency, as stated in [17]. Therefore, the addition of excess graphite did not have a significant effect on the leaching of $\mathrm{Li}$.

Another method to improve $\mathrm{Li}$ leachability can be with the use of supercritical $\mathrm{CO}_{2}$ as reported in [20], where Li efficiency was 79\%.
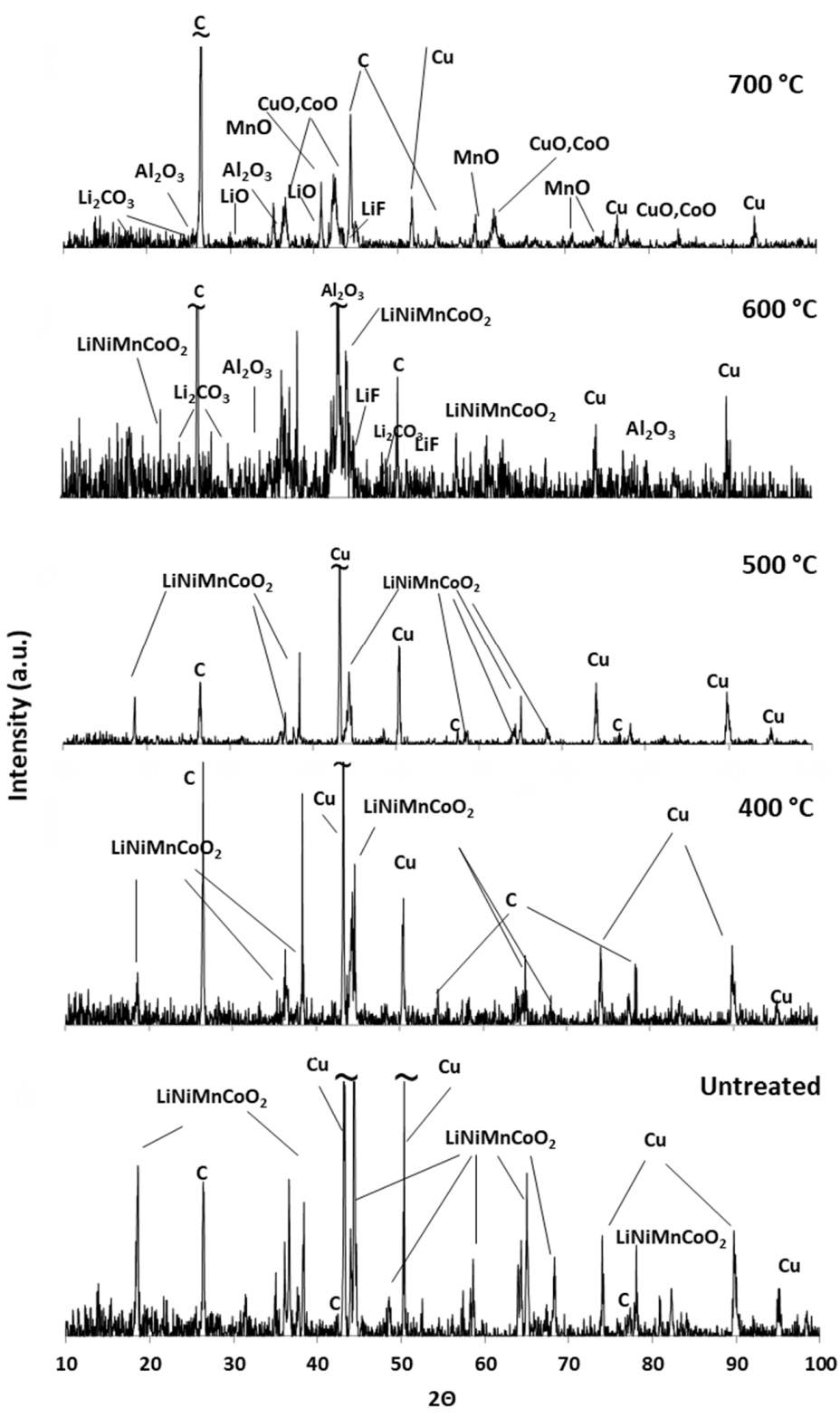

Figure 6. XRD diffractogram of residue after leaching pyrolyzed samples. 


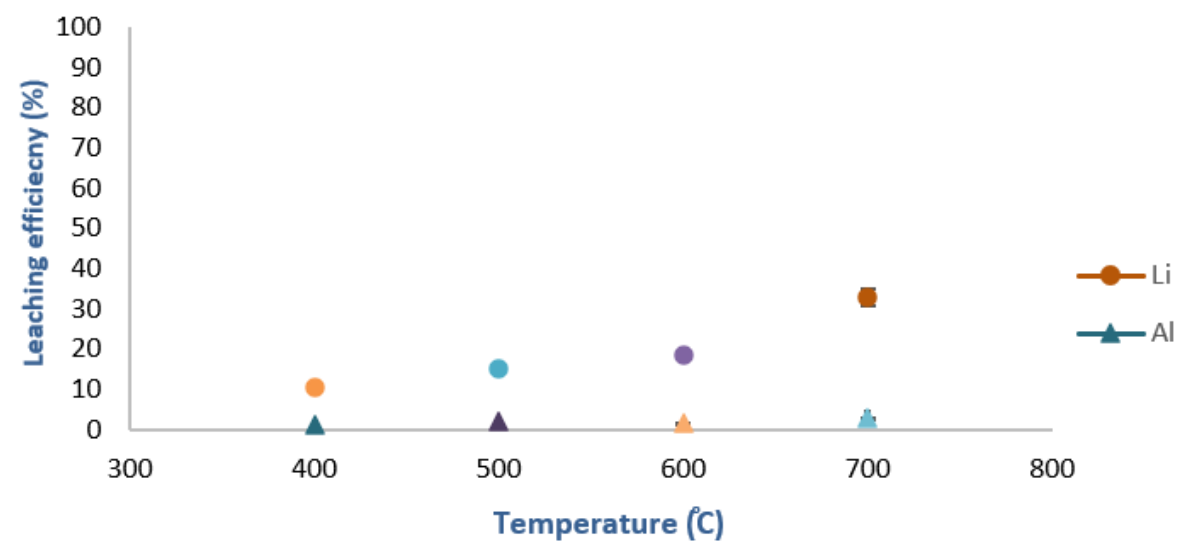

Figure 7. The effect of $10 \%$ excess of carbon on leaching of $\mathrm{Li}$ and $\mathrm{Al}$ from pyrolyzed samples. (Leaching condition: $\mathrm{L} / \mathrm{S}$ ratio $=20: 1 \mathrm{~mL} \mathrm{~g}^{-1}, 80^{\circ} \mathrm{C}, 300 \mathrm{rpm}$, and $1 \mathrm{~h}$ ).

\subsection{Leaching of $\mathrm{Al}$}

$\mathrm{Al}$ exits in both untreated and thermally treated samples in different forms such as alloys, metallic $\mathrm{Al}$, salts, and $\mathrm{Al}_{2} \mathrm{O}_{3}$ which could be formed by the oxidation of $\mathrm{Al}$. However, the presence of salts was not detected by XRD analysis. Along with $\mathrm{Li}$, a very small amount of $\mathrm{Al}$ was also found to be leached at all the treatment conditions. Al was found in the form of $\mathrm{AlF}_{3}$ in the leaching residue of the thermally pretreated samples. This may be from the $\mathrm{AlF}_{3}$ used as a protective coating for the electrode materials $[21,22]$ or could be formed by the reaction of $\mathrm{HF}$ with $\mathrm{Al}$ and $\mathrm{Al}_{2} \mathrm{O}_{3}$ according to Equations (31) and (32) [23,24]. Also, the presence of $\mathrm{AlF}_{3}$ was confirmed in the XRD analysis of the crystallization product as shown in Figure 4. Although $\mathrm{Al}_{2} \mathrm{O}_{3}$ was observed in XRD analysis, it is not expected to be leached with water as it shows resistance to acid attack, even by aqua regia [12]. However, the Al leaching efficiency in the sample obtained from both thermal treatments was not higher than $3.5 \%$.

$$
\begin{aligned}
& \text { 2. } \mathrm{Al}+6 \mathrm{HF} \rightarrow 2 \mathrm{AlF}_{3}+3 \mathrm{H}_{2} \\
& \mathrm{Al}_{2} \mathrm{O}_{3}+6 \mathrm{HF} \rightarrow 2 \mathrm{AlF}_{3}+3 \mathrm{H}_{2}
\end{aligned}
$$

\subsection{Effect of Thermal Treatment Temperature on the Leaching Efficiency of Al}

The effect of thermal treatment temperature on the leaching efficiency of Al from the samples pyrolyzed and incinerated between $400-700{ }^{\circ} \mathrm{C}$ for 30,60 , and 90 min are shown in Figure 1a,b. It can be seen that both thermal treatments show a maximum of $3.5 \% \mathrm{Al}$ leaching efficiency at $700{ }^{\circ} \mathrm{C}$. At higher temperatures, the concentration of $\mathrm{Al}$ was found to increase by nearly $50 \%$ in the sample treated at $700{ }^{\circ} \mathrm{C}$, compared to the untreated sample, under both types of thermal treatment processes. Also, the $\mathrm{Al}$ leaching efficiency of the untreated sample was $0.47 \%$. The low leaching efficiency of $\mathrm{Al}$ can be considered positive for the further obtainment of a lithium product, for example by evaporative crystallization, with higher purity.

\subsection{Effect of L/S Ratio on the Leaching Efficiency of $A l$}

The effect of $\mathrm{L} / \mathrm{S}$ ratio on leaching of $\mathrm{Al}$ performed at $80{ }^{\circ} \mathrm{C}$, stirring of $300 \mathrm{rpm}$ for $3 \mathrm{~h}$ at two different $\mathrm{L} / \mathrm{S}$ ratios of 10:1 and $20: 1 \mathrm{~mL} \mathrm{~g}^{-1}$, from samples pyrolyzed and incinerated between 400 and $700{ }^{\circ} \mathrm{C}$ for 30,60 , and $90 \mathrm{~min}$ is shown in the Figure 8a,b. It can be seen that leaching efficiency obtained at both the conditions at different $\mathrm{L} / \mathrm{S}$ show similar trends, but the efficiency increases with increasing L/S ratio. A higher L/S ratio results in higher leaching efficiency when the dissolution of $\mathrm{Al}$ is limited by the solubility.

\subsection{Effect of Leaching Temperature on the Leaching Efficiency of Al}

The effect of leaching temperature on leaching of Al performed at stirring of $300 \mathrm{rpm}$ for $3 \mathrm{~h}$ with an $\mathrm{L} / \mathrm{S}$ ratio $20: 1 \mathrm{~mL} \mathrm{~g}^{-1}$ at two different leaching temperatures: $80^{\circ} \mathrm{C}$ and $\mathrm{RT}$ 
from samples pyrolyzed and incinerated between 400 and $700{ }^{\circ} \mathrm{C}$ for 30,60 , and $90 \mathrm{~min}$ is shown in the Figure 9a,b. It is evident that the leaching of $\mathrm{Al}$ increases with an increase in the temperature. However, Al leaching efficiency of less than $0.5 \%$ and almost no leaching from pyrolyzed and incinerated samples, respectively, were observed at RT. This is because the solubility of the $\mathrm{AlF}_{3}$ increases with an increase in the temperature. For example, the aqueous solubility of $\mathrm{AlF}_{3}$ at $25^{\circ} \mathrm{C}$ and $100{ }^{\circ} \mathrm{C}$ is 0.5 and $1.28 \mathrm{~g} / 100 \mathrm{~mL}$, respectively [18].

\subsection{Effect of Addition of Excess Carbon}

The effect of using excess carbon on leaching of Al performed at a stirring of $300 \mathrm{rpm}$ for $1 \mathrm{~h}$ with an $\mathrm{L} / \mathrm{S}$ ratio $20: 1 \mathrm{~mL} \mathrm{~g}^{-1}$ at $80^{\circ} \mathrm{C}$ from samples pyrolyzed at $400,500,600$, and $700{ }^{\circ} \mathrm{C}$ for $30 \mathrm{~min}$ is shown in Figure 7. It can be observed that not much variation in leaching of $\mathrm{Al}$ was observed having additional carbon during the thermal treatment and the efficiency was less than $3 \%$. Therefore, the addition of excess carbon did not have much effect on Al leaching.
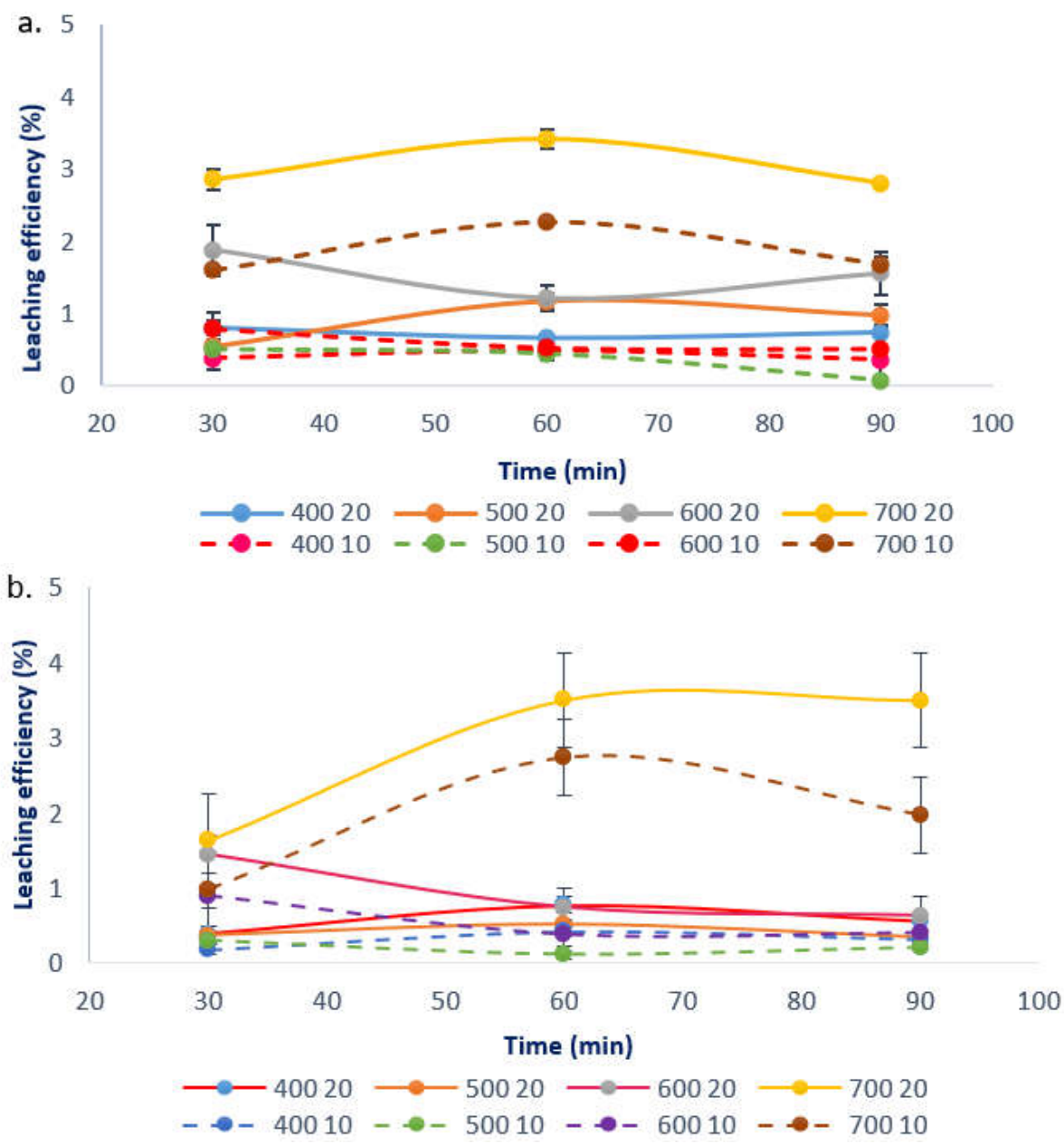

Figure 8. The effect of L/S ratio on Al leaching efficiency: (a) pyrolysis and (b) incineration (Leaching condition: $\mathrm{L} / \mathrm{S}$ ratio $=20: 1$ and $10: 1 \mathrm{~mL} \mathrm{~g}^{-1}, 80^{\circ} \mathrm{C}, 300 \mathrm{rpm}$, and $3 \mathrm{~h}$ ). 

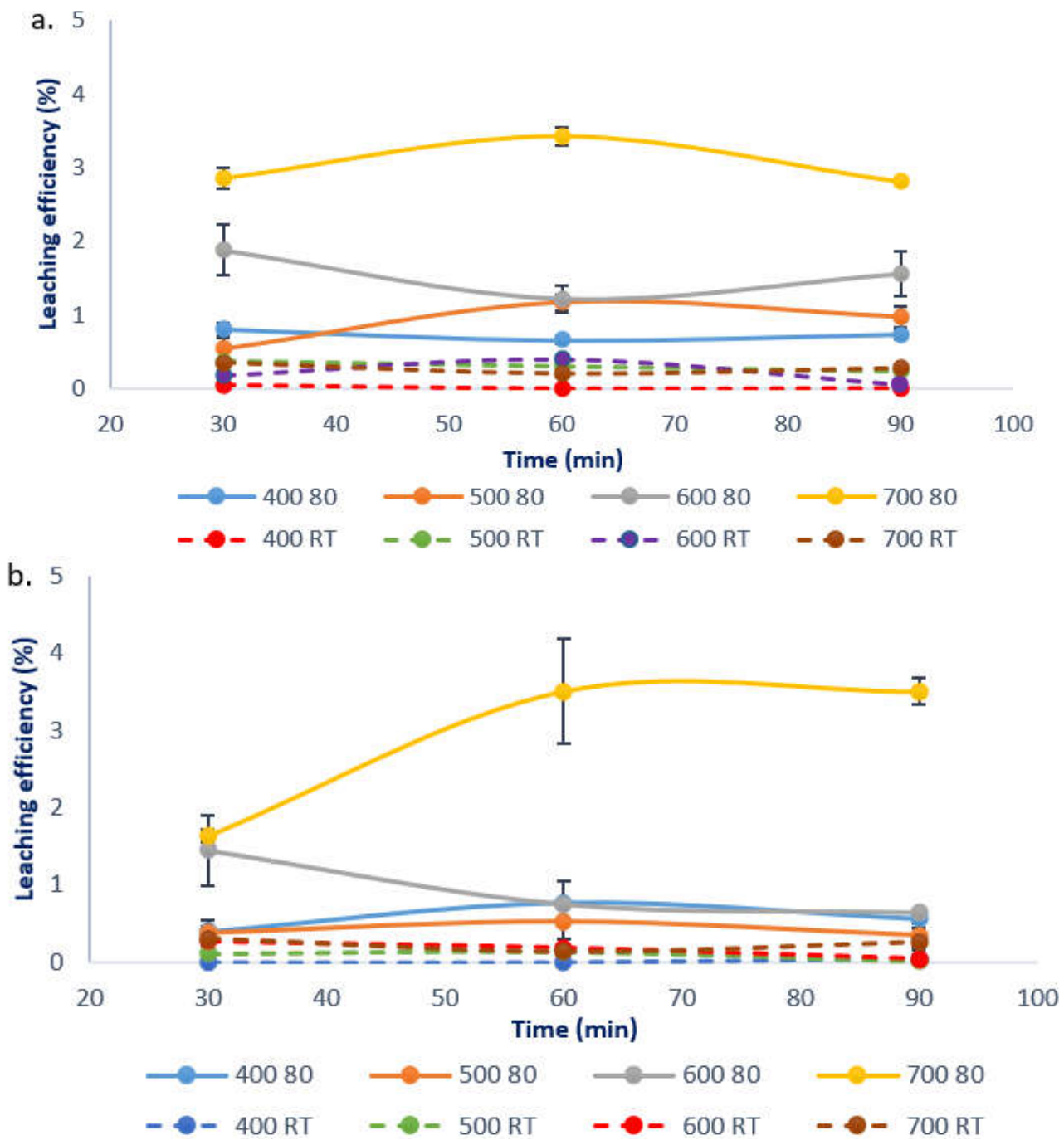

Figure 9. The effect of leaching temperature on Al leaching efficiency: (a) pyrolysis and (b) incineration (Leaching condition: (a). L/S ratio $=20: 1 \mathrm{~mL} \mathrm{~g}^{-1}, 80^{\circ} \mathrm{C}$ and $\mathrm{RT}, 300 \mathrm{rpm}$, and $3 \mathrm{~h}$ ).

\section{Conclusions}

The leaching efficiency of Li from spent LIBs pretreated thermally by pyrolysis and incineration processes was investigated. The results show that Li could be separated and selectively recovered from the black mass. It was found that the leaching efficiency of $\mathrm{Li}$ from the pyrolyzed samples was higher than that from the incinerated samples. An increase in the thermal pretreatment temperature from 400 to $700{ }^{\circ} \mathrm{C}$ resulted in an increase in $\mathrm{Li}$ leaching efficiency, which could be favored by the removal of organic compounds such as the binder, which can hinder the recovery of Li from the electrode materials. Furthermore, the time of thermal pretreatment does not have much influence on the Li leaching efficiency, which might be due to the conversion of lithium metal oxides into Li salts within $30 \mathrm{~min}$. After longer times, there might be an incomplete conversion of $\mathrm{Li}_{2} \mathrm{O}$ to $\mathrm{Li}_{2} \mathrm{CO}_{3}$ due to the removal of gaseous products such as $\mathrm{CO}$ and $\mathrm{CO}_{2}$ by the constant flow of $\mathrm{N}_{2}$ needed for the reduction during pyrolysis. During the incineration, most of the carbon was lost after 30 min of treatment due to oxidation and much less remained for carbothermic reduction of metal oxides. However, the highest Li leaching efficiency of nearly $60 \%$ was observed from the sample pyrolyzed at $700{ }^{\circ} \mathrm{C}$ for $60 \mathrm{~min}$ and water leached under an L/S ratio of $20: 1 \mathrm{~mL} \mathrm{~g}^{-1}$ at $80^{\circ} \mathrm{C}$ and $300 \mathrm{rpm}$ for $3 \mathrm{~h}$. The results from the comparison of the effect of $\mathrm{L} / \mathrm{S}$ ratio on leaching of $\mathrm{Li}$ performed at $80^{\circ} \mathrm{C}$, showed that the leaching efficiency of $\mathrm{Li}$ was higher with higher $\mathrm{L} / \mathrm{S}$ ratio. At a higher leaching temperature, the leaching of $\mathrm{Li}$ is 
higher due to an increase in the solubility of Li salts at higher temperatures. Additionally, the formation of $\mathrm{LiF}$ was observed by the reaction of $\mathrm{Li}_{2} \mathrm{O}$ and $\mathrm{Li}_{2} \mathrm{CO}_{3}$ with $\mathrm{HF}$ generated by the decomposition of the PVDF binder. The reason for low Li efficiency $(60 \%)$ could be due to unreacted NMC cathode materials during thermal treatment or incomplete leaching of Li salts and oxides by water. Therefore, to enhance the efficiency, tests were conducted using $10 \%$ of excess carbon in the form of graphite. However, there was no significant improvement in the leaching efficiency. The reason could be due to the stability of graphite which might not have completely taken part in the reduction process. Furthermore, some $\mathrm{Al}$ was also found to be leached with a leaching efficiency not higher than 3.5\%.

Author Contributions: Conceptualization, methodology, software: S.B., N.V. and M.P.; validation: S.B., N.V., K.F. and M.P., formal analysis, investigation, data curation: S.B., T.L. and G.L. resources, M.P.; writing — original draft preparation: S.B.; writing—review and editing, visualization, supervision, M.P, N.V. and K.F.; project administration, M.P..; funding acquisition, M.P. All authors have read and agreed to the published version of the manuscript."

Funding: This research was funded by ÅForsk (grant number: 19-695) and VINNOVA (grant number: 2020-04463).

Institutional Review Board Statement: Not applicable.

Informed Consent Statement: Not applicable.

Data Availability Statement: The data presented in this study are available on request from the corresponding author.

Conflicts of Interest: The authors declare no conflict of interest.

\section{References}

1. Drabik, E.; Rizos, V. Prospects for electric vehicle batteries in a circular economy. CEPS Res. Rep. 2018, 20.

2. Li, J.; Wang, G.; Xu, Z. Environmentally-friendly oxygen-free roasting/wet magnetic separation technology for in situ recycling cobalt, lithium carbonate and graphite from spent LiCoO2/graphite lithium batteries. J. Hazard. Mater. 2016, 302, 97-104. [CrossRef] [PubMed]

3. Söderman, M.L.; Kushnir, D.; Sandén, B. Will metal scarcity limit the use of electric vehicles? Syst. Perspect. Electromobility 2013, 76-89.

4. Peng, C.; Liu, W.; Wang, Z.; Wilson, B.P.; Lundström, M. Selective extraction of lithium (Li) and preparation of battery grade lithium carbonate $\left(\mathrm{Li}_{2} \mathrm{CO}_{3}\right)$ from spent Li-ion batteries in nitrate system. J. Power Sources 2019, 415, 179-188. [CrossRef]

5. Greim, P.; Solomon, A.A.; Breyer, C. Assessment of lithium criticality in the global energy transition and addressing policy gaps in transportation. Nat. Commun. 2020, 11, 4570. [CrossRef] [PubMed]

6. Agusdinata, D.B.; Liu, W.; Eakin, H.; Romero, H. Socio-environmental impacts of lithium mineral extraction: Towards a research agenda. Environ. Res. Lett. 2018, 13, 123001. [CrossRef]

7. Wanger, T.C. The Lithium future-Resources, recycling, and the environment. Conserv. Lett. 2011, 4, 202-206. [CrossRef]

8. European Commission. Study on the EU's List of Critical Raw Materials-Final Report (2020); European Commission: Brussels, Belgium, 2020.

9. Graedel, T.E.; Allwood, J.; Birat, J.P.; Reck, B.K.; Sibley, S.F.; Sonnemann, G.; Buchert, M.; Hageluken, C. Recycling Rates of Metals-A Status Report. A Report of the Working Group on the Global Metal Flow to the International Resource Panel; UNEP: Nairobi, Kenya, 2011.

10. Zhao, Y.; Liu, B.; Zhang, L.; Guo, S. Microwave-absorbing properties of cathode material during reduction roasting for spent lithium-ion battery recycling. J. Hazard. Mater. 2020, 384, 121487. [CrossRef] [PubMed]

11. Xiao, J.; Li, J.; Xu, Z. Novel approach for in situ recovery of lithium carbonate from spent lithium ion batteries using vacuum metallurgy. Environ. Sci. Technol. 2017, 51, 11960-11966. [CrossRef] [PubMed]

12. Lombardo, G. Effects of Pyrolysis and Incineration on the Chemical Composition of Li-Ion Batteries and Analysis of the by-Products. Ph.D. Thesis, Chalmers University of Technology, Goteborg, Sweden, 2019.

13. Ekberg, C.; Petranikova, M. Lithium Batteries Recycling. In Lithium Process Chemistry; Elsevier Inc.: Amsterdam, The Netherlands, 2015; pp. 233-267. ISBN 978-0-12-801417-2.

14. Kuzuhara, S.; Ota, M.; Tsugita, F.; Kasuya, R. Recovering lithium from the cathode active material in lithium-ion batteries via thermal decomposition. Metals 2020, 10, 433. [CrossRef]

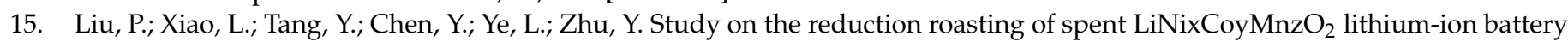
cathode materials. J. Therm. Anal. Calorim. 2019, 136, 1323-1332. [CrossRef]

16. Jandova, J.; Dvorak, P.; Kondas, J.; Havlak, L. Recovery of lithium from waste materials. Ceram. Silikáty 2012, 56, 50-54. 
17. Paulino, J.F.; Busnardo, N.G.; Afonso, J.C. Recovery of valuable elements from spent Li-batteries. J. Hazard. Mater. 2008, 150, 843-849. [CrossRef] [PubMed]

18. Lide, D.R. CRC Handbook of Chemistry and Physics; Internet Version 2005; CRC Press: Boca Raton, FL, USA, 2005. Available online: http:/ / www.hbcpnetbase.com (accessed on 12 December 2020).

19. Xue, S.; Zhang, L.; Han, Z.; Huang, X. Reaction mechanism between oxide film on surface of Al-Li alloy and CsF-AlF 3 flux. Trans. Nonferrrous Met. Soc. China 2008, 18, 121-125. [CrossRef]

20. Schwich, L.; Schubert, T.; Friedrich, B. Early-Stage Recovery of Lithium from Tailored Thermal Conditioned Black Mass Part I: Mobilizing Lithium via Supercritical $\mathrm{CO}_{2}$-Carbonation. Metals 2021, 11, 177. [CrossRef]

21. Zheng, J.M.; Zhang, Z.R.; Xu, X.B.; Dong, Z.X.; Zhu, Z.; Yang, Y. The effect of $\mathrm{AlF}_{3}$ coating on the performance of $\mathrm{Li}\left[\mathrm{Li} 0.2 \mathrm{Mn} 0.54 \mathrm{Ni0} .13 \mathrm{Co} 0.13 \mathrm{O}_{2}\right.$ positive electrode material for lithium-ion battery. J. Electrochem. Soc. 2008, 155, A775-A782. [CrossRef]

22. Julien, C.M.; Mauger, A. Functional behavior of AlF3 coatings for high-performance cathode materials for lithium-ion batteries. AIMS Mater. Sci. 2019, 6, 406-440. [CrossRef]

23. Vargel, C. Inorganic Acids. In Corrosion of Aluminium; Elsevier: Amsterdam, The Netherlands, 2004; pp. 397-414, ISBN 9780080444956. [CrossRef]

24. Cano, A.M.; Marquardt, A.E.; DuMont, J.M.; George, S.M. Effect of HF pressure on Thermal $\mathrm{Al}_{2} \mathrm{O}_{3}$ atomic layer etch rates and $\mathrm{Al}_{2} \mathrm{O}_{3}$ fluorination. J. Phys. Chem. 2019, 123, 10346-10355. [CrossRef] 